
mutatóik idősorai alapján

A vállalatok felszámolásának előrejelzésében általános gyakorlat a számviteli adatokból kapott hányados típusú pénzügyi mutatók használata. E mutatókat általában csak az utolsó lezárt üzleti év adatai alapján kalkulálják. Az így felépített modellek azonban statikus jellegüek, s nem veszik figyelembe a vállalati gazdálkodás folyamatjellegét. E hiányosság kiküszöbölésére korábban Nyitrai [2014a] tett kísérletet a statikus pénzügyi mutatószámok idősoraiból képzett, úgynevezett dinamikus pénzügyi mutatók használatával - azonban számos, önkényesnek tünő feltételezéssel élt, amelyek közül tanulmányunkban kettőt feloldunk. Az idézett cikk csak döntési fák segítségével vizsgálta a pénzügyi mutatók időbeli trendjét kifejező változó hatékonyságát. Most e megközelítés hatását a modellek előrejelző képességére a - szakirodalomban általánosan elterjedt - logisztikus regresszió keretei között vizsgáljuk meg. Nyitrai [2014a] a pénzügyi mutatók teljes idősorait felhasználta, ennek szükségessége kérdéses lehet, ezért megnézzük a csődmodellek előrejelző képességét annak függvényében, hogy hány évre visszamenően vesszük figyelembe a pénzügyi mutatók értékeit. Journal of Economic Literature (JEL) kód: C52, C53, G33.

A vállalatok jövőbeli fizetőképességének előrejelezhetősége kutatási kérdésként meglehetősen nagy múltra tekint vissza, ugyanis így most múlt fél évszázada annak, hogy Beaver [1966] lefektette a témakör tudományos alapköveit. A hosszú évtizedek során a téma iránti kutatói érdeklődés egyre fokozódik. A vállalkozások fizetésképtelenségének jelentős közvetlen és közvetett költsége van, amelyeknek az elkerülése, illetve minimalizálása a vállalatok valamennyi érdekcsoportja számára lényeges kérdés. Ebből adódóan nevezi Kim-Kang [2012] a csődelőrejelzést a pénzügyi és számviteli szakirodalom egyik legfontosabb területének.

* Köszönjük a lektor segítőkész tanácsait, amelyek nagyban hozzájárultak a tanulmány színvonalának növeléséhez.

Nyitrai Tamás tudományos segédmunkatárs, Budapesti Corvinus Egyetem Vállalkozások Pénzügyei Tanszék (e-mail: nyitrai.tamas@hotmail.com).

Virág Miklós tanszékvezető egyetemi tanár, Budapesti Corvinus Egyetem Vállalkozások Pénzügyei

Tanszék (e-mail: miklos.virag@uni-corvinus.hu).

A kézirat első változata 2016. február 15-én érkezett szerkesztőségünkbe.

DOI: http://dx.doi.org/10.18414/KSZ.2017.3.305 
A csődelörejelző modellek jellemzően olyan kvantitatív modellek, amelyeknek függő változója a vállalkozások aktuális állapota a (fizetőképes vagy fizetésképtelen) $t$-edik évben, független változói pedig a $(t-1)$-edik év számviteli adataiból kalkulálható hányados típusú pénzügyi mutatószámok (Zhou [2013]). Ennek megfelelően a csődelörejelzés outputja az előbb említett függő és független változók közti sztochasztikus kapcsolatrendszer leképezése matematikai formában. Ha feltételezhető, hogy ez a kapcsolat időben állandó, akkor a feltárt matematikai összefüggés alkalmas lehet a vállalatok jövőbeli fizetőképességének előrejelzésére.

A csődelörejelzés lényegének iménti összefoglalása azonban közel sem tekinthető pontos definíciónak, mindössze kísérletnek azon tendencia megfogalmazására, amely a témakör hazai és nemzetközi szakirodalmából fóáramú trendként kiolvasható. Hangsúlyoznunk kell ugyanis, hogy a tudományos publikációk szerzői között nincs konszenzus sem a függő, sem a független változók operacionalizálása tekintetében. Számos kutatás a vállalatok jogi értelemben vett csődjét próbálja elöre jelezni (bankruptcy prediction), míg mások véleménye szerint a csőd bekövetkezésének előrejelzése már túlságosan késői figyelmeztetés, így a szakirodalomban találkozhatunk olyan empirikus vizsgálatokkal is, amelyek célja a vállalatok pénzügyi nehézségeinek elörejelzése (financial distress prediction) (lásd például Platt-Platt [2002]).

Bármelyikröl legyen is szó a fentiek közül, abban a tekintetben mindenképpen egységesnek tekinthető a szakirodalom, hogy a kutatási terület célja a modellek elörejelző képességének növelése (Du Jardin [2010]). Tanulmányunkban mi is ezt a célt tüztük magunk elé. A csődelőrejelzés tudománytörténetének eddig eltelt öt évtizedében a kutatók elsősorban módszertani oldalról tettek kísérletet a modellek elörejelző teljesítményének fokozására. Bár a módszertani összehasonlító elemzések jellemzik e terület fóáramát, a modellek teljesítménye nemcsak módszertani oldalról javítható, hanem a magyarázó változók körének bővítésével, illetve információtartalmuk lehetö legnagyobb mértékű kihasználásával is.

Munkánk az utóbb említett körbe sorolható, mivel a szakterületen általánosan elterjedt logisztikus regresszió módszerét alkalmazza. A választás oka, hogy a vállalatok jövőbeli csődjének tudományos kutatásában és a gyakorlati alkalmazás során is túlnyomó többségben vannak a viszonylag egyszerü matematikai hátterü klasszifikációs módszerek (Riberio és szerzőtársai [2012]). Mindez azonban nem jelenti azt, hogy megközelítésünk csak e módszertani háttér keretei között lenne alkalmazható. A Nyitrai [2014a] által javasolt dinamizálási metódus előnye, hogy bármely klasszifikációs eljárás során használható, épp ez motivált bennünket arra, hogy alaposabb vizsgálatnak vessük alá.

Bár a csődelőrejelző modellek gyakorlati alkalmazása kapcsán leggyakrabban a hitelkockázati modellezést említik, ez nem kizárólagos alkalmazási terület: fejlett piacgazdaságokban üzleti partnerek pénzügyi minősítése során is alkalmazzák őket. Az utóbbi években több olyan vállalkozás indult Magyarországon is, amelyek hasonló tevékenységgel foglalkoznak. Emellett releváns lehet az állami szabályozás és a nemzetgazdaság egésze szempontjából is, ugyanis a vállalati csödök száma a gazdaság egészének teljesítménye szempontjából fontos mutató, így a vállalatok 
jövőbeli fizetésképtelenségének minél pontosabb elörejelzése makrogazdasági szempontból sem elhanyagolható kérdés.

A csődelőrejlelző modelleket jellemzően a számviteli adatokból kalkulálható hányados típusú pénzügyi mutatószámok értékeire alapozzák. E változókör hatékonyságát igazolja, hogy az 1960-as évektől folyamatosan alkalmazzák őket a független változók között (Chen [2012]). E pénzügyi mutatószámok értékeit jellemzően a fizetésképtelenség bekövetkezését közvetlenül megelőző év adatai alapján számítják ki, mivel kétségtelenül ezek az adatok mutatnak leginkább eltérést a továbbra is fizetőképes vállalatokhoz képest. Ezzel a megközelítéssel viszont csak statikusan veszik figyelembe a vállalatok pénzügyi helyzetét, és figyelmen kívül hagyják a pénzügyi mutatószámok idősoraiból (tendenciáiból) nyerhető információkat (Chen és szerzőtársai [2013]).

Nwogugu [2007] szerint a statikus pénzügyi mutatókra épített csődelörejelző modellek rosszul specifikáltak, mivel a pénzügyi nehézségek kialakulása időbeli folyamat, amelyet a modellezés során is figyelembe kell venni. Hasonlóképpen vélekedik a kérdésről Niklis és szerzőtársai [2014] is: a pénzügyi mutatók dinamikájának figyelembevétele fontos jövőbeli kutatási irány a csődelőrejelzésben. A hazai szakirodalomban Nyitrai [2014a] ezt a célt egy olyan változó bevezetésével próbálta megvalósítani, amely kifejezi, hogy miként viszonyul a pénzügyi mutatók legutoljára megfigyelt értéke az azt megelőző időszak értékeihez. A tanulmány empirikus eredményei ígéretesek, de számos kérdés nyitva maradt, amelyek további vizsgálatot igényelnek. Egyrészt a javasolt mutatók hatását a modellek elörejelző teljesítményére csak a döntési fák keretei közt vizsgálta, másrészt a pénzügyi mutatók teljes idősorát felhasználta, ami jelentős adatigényt támaszt a módszert alkalmazni kívánó modellező elé. Ebből adódóan felvetődik a kérdés: szükséges-e a pénzügyi mutatók teljes idősora a modellek elörejelző teljesítményének növeléséhez, illetve hogyan befolyásolja a dinamikus pénzügyi mutatókat ${ }^{1}$ is tartalmazó modellek elörejelző teljesítményét a figyelembe vett idősor hossza.

Tanulmányunk a fentiek alapján a következő két kérdésre keres választ.

1. A logisztikus regresszió módszertani keretei közt is növeli-e a modellek elörejelzö képességét a Nyitrai [2014a] által javasolt dinamikus pénzügyi mutatók alkalmazása?

2. Befolyásolja-e a fenti változókat is tartalmazó modellek előrejelző teljesítményét a figyelembe vett idősorok hossza?

Tanulmányunk felépítése a következő: elhelyezzük kutatásunkat a csődelőrejelzés szakirodalmán belül, kitérve a választott téma kapcsán legfontosabbnak vélt tanulmányokra. Ismertetjük a dinamikus pénzügyi mutatók számítását. Bemutatjuk az empirikus vizsgálathoz felhasznált kutatási adatbázist, valamint a számítások eredményeit. Végül összefoglaljuk a tanulmányból levonható következtetéseket, és kitérünk az azokból fakadó további kutatási lehetőségekre.

\footnotetext{
${ }^{1}$ A dinamikus pénzügyi mutatókról lásd bővebben Nyitrai [2014a].
} 


\section{Szakirodalmi áttekintés}

A vállalkozások jövőbeli fizetőképességével kapcsolatos bizonytalanság meglehetösen korán a kutatói érdeklődés középpontjába került. Az első tudományos eszköztárral végzett elemzés Beaver [1966] nevéhez kötődik. A szerző a pénzügyi kimutatások adataiból leggyakrabban számított pénzügyi mutatószámokat hasonlította össze abból a szempontból, hogy melyik és milyen mértékben képes a vállalatok jövőbeli csődjének előrejelzésére 1-5 éves időtávon. Ezt a megközelítést egyváltozós diszkriminanciaanalízisként ismeri a szakirodalom. Gyorsan nyilvánvalóvá vált azonban, hogy ez az elörejelzés nem alapozható mindössze egyetlen pénzügyi mutatószám vizsgálatára. A Beaver [1966] által javasolt elemzés ugyan elvégezhető többféle mutatóval is, ám könnyen előfordulhat, hogy az egyes mutatók alapján készíthető előrejelzések közt ellentmondást tapasztalunk. Reális feltevés ugyanis, hogy amíg egy vállalat likviditási helyzete alapján a jövőben fizetőképesnek minősíthető, addig adósságmutatói akár azt is jelezhetik, hogy jobban hasonlít a csődbe ment vállalkozásokhoz, mert például egy jelentős beruházást hitelből valósított meg. Ez az eset rámutat arra, hogy a csődelőrejelzés több magyarázó változó szimultán figyelembevételét igényli - mégpedig fontossági súlyuknak megfelelően. E célok elérése megkerülhetetlenné tette a többváltozós matematikai-statisztikai módszerek megjelenését a csődelörejelzésben. Ezen eljárások közül elsőként a többváltozós diszkriminanciaanalízis jelent meg Altman [1968] munkájában.

Az imént említett módszer azonban olyan feltételezésekkel él a magyarázó változókkal szemben (például normális eloszlás, függetlenség stb.), amelyek a tudományterületen általánosan elterjedt pénzügyi mutatók esetében jellemzően nem teljesülnek, így a kutatói érdeklődés az 1980-as évektől kezdődően a kevésbé restriktív statisztikai módszerek irányába fordult. E körből elöször a logisztikus regresszió alkalmazása jelent meg, és ez tekinthető dominánsnak a mai napig. Az 1990-es években a módszertani fejlődésnek köszönhetően általánosan elterjedtté váltak az adatbányászati módszerek, illetve a mesterséges intelligencia eszközei, amelyek előfeltevések nélkül képesek a csődesemény bekövetkezése és a pénzügyi mutatószámok közt tapasztalható komplex, jellemzően nemlineáris kapcsolatrendszer leképezésére (Du Jardin [2010]). Az ígéretes eredmények ellenére máig nem alakult ki konszenzus arra vonatkozóan, hogy melyik módszert érdemes a leginkább alkalmazni a csődelőrejelzésben, mivel gyakori tapasztalat, hogy egyes adathalmazoknál az egyik, míg más megfigyelések esetén egy másik eljárás adja a legjobb teljesítményt (Oreski és szerzőtársai [2012]). Mivel a legtöbb tanulmány a különböző módszerek klasszifikációs teljesítményének összevetésével foglalkozik, ezek a módszertani összehasonlító vizsgálatok tekinthetök a csődelörejelzés kutatásában a fóáramnak (Sánchez-Lasheras és szerzőtársai [2012]).

Fontos azonban felhívni a figyelmet Sun [2007] azon megállapítására, hogy a modellek elörejelző képessége nem csak új módszerek alkalmazásával javítható. Erre lehetőséget teremt a magyarázó változók körének szélesítése és minőségének javítása is. Ebben a körben a leggyakoribb példa a kvantitatív pénzügyi adatok mellett a kvalitatív szempontok figyelembevétele. Számos empirikus vizsgálat igazolta, hogy a vállalatok 
jövőbeli fennmaradását és fizetőképességét olyan kvalitatív tényezők is befolyásolhatják, amelyek nem jelennek meg közvetlenül a vállalatok pénzügyi kimutatásaiban.

Más szerzők a pénzügyi mutatók információtartalmát próbálják növelni oly módon, hogy értéküket nem közvetlenül használják fel magyarázó változóként, hanem valamilyen viszonyítási alap segítségével igyekeznek megítélni a vállalatok pénzügyi teljesítményét. Ennek oka, hogy a pénzügyi mutatószámok esetében nem állapítható meg objektíven és egységesen bármely vállalatra, hogy mely érték mondható egyértelmüen „jónak” vagy „rossznak” (Emel és szerzőtársai [2003]). A viszonyítás tekintetében alapvetően három lehetőség adódik:

- a pénzügyi mutatók átlagos értéke az adott iparágban (Platt-Platt [1990]),

- a versenytársak megfelelő mutatói (Zhou és szerzőtársai [2012]), valamint

- a vállalat saját adatai a korábbi évekből (Zhou és szerzőtársai [2012]).

Az iparági átlaghoz (vagy más középértékhez) történő viszonyítás célszerű választásnak tűnhet, ám alkalmazásakor számos nehézség merülhet fel. A legalapvetőbb probléma, hogy az iparági szintű adatok Magyarországon nem nyilvánosak. A másik kérdés az iparági középértékek alkalmazhatóságával kapcsolatos. Általánosnak mondható ugyanis, hogy egy-egy vállalat jellemzően nemcsak egy adott tevékenységgel foglalkozik, hanem tevékenységek szélesebb körével (Emel és szerzőtársai [2003]). Ez azért jelent problémát, mert az iparági középértékek meghatározásánál a csoportképzés alapja a TEÁOR-kód alapján definiált főtevékenység. Ebben a tekintetben viszont kérdéses lehet, hogy az ennek alapján egy ,iparágba” sorolt vállalkozások mutatóinak átlaga mennyire tekinthető megbízható viszonyítási alapnak olyan vállalkozások esetében, amelyek egyidejüleg több tevékenységet is folytatnak.

A versenytársak pénzügyi adataihoz való hasonlítás szintén gyakran alkalmazott megoldás a vállalati pénzügyekben. A közvetlen összevethetöség azonban itt is sok esetben korlátozott. Ezt a problémát a vállalatértékelés során például különböző diszkontfaktorok formájában szakértői alapon végzett korrekciókkal oldják meg. A vállalatértékelési gyakorlatban a megközelítés adekvát, azonban ennek adaptációja a csődelőrejelzésben a tudományterület alapelveinek sérüléséhez vezetne, ugyanis ezzel az elemző szubjektív értékítélete is szerepet kapna a modellezésben, amelynek épp az objektivitás lenne az egyik sarokpontja (Virág és szerzőtársai [2013]). Másrészröl ez jelentősen lassítaná a modellépítés folyamatát, növelné a modellépítés emberierőforrásigényét, és korlátozná a vállalatminősítés automatizálhatóságát - e tényezők szintén fontos hajtóerői a csődelőrejelzés tudományterületének.

$\mathrm{Az}$ eddig felsorolt problémák azonban nem merülnek fel abban az esetben, ha a vállalatok pénzügyi mutatóit saját korábbi értékeikhez viszonyítjuk. Ebben az esetben ugyanis a közvetlen összevethetöség jóval kevésbé korlátozott. A vállalatok gazdálkodási tevékenysége egy folyamat, amelynek aktuális állapotáról a pénzügyi beszámolók adnak egy-egy pillanatfelvételt a fordulónap időpontjában. Ha nemcsak a legutolsó felvételt tekintjük, hanem a megelőző időszakok tükrében is vizsgálódunk, akkor képet kaphatunk a vállalat korábbi éveihez viszonyított pénzügyi helyzetéröl. Nwogugu [2006] szerint a csődhöz vezető pénzügyi nehézségek kialakulása időbeli folyamat, s azt is figyelembe kell venni, hogy a vállalatban épp kialakulóban vannak 
a problémák, vagy már elkezdődött a kilábalás időszaka. A statikus mutatók azonban ezt nem képesek tükrözni.

A pénzügyi mutatószámok időbeli tendenciáinak megragadására a Nyitrai [2014a] által javasolt formula jól alkalmazható keresztmetszeti módszer. Döntési fák segítségével számottevően javult a modellek elörejelző képessége, ami további vizsgálatok is megerősítettek szigorúbb validációs eljárások (Nyitrai [2014b]) és más döntésifamódszerek esetében (Virág-Nyitrai [2015]). Ezek a kutatások azonban több kérdést nem tisztáztak egyértelmüen a dinamizálás megjelenítésére javasolt változó kapcsán, ezek közül kettőt tárgyalunk meg a későbbiekben.

\section{Dinamikus pénzügyi mutatószámok}

A pénzügyi mutatószámok időbeli tendenciájának modellbe építésére Nyitrai [2014a] az (1) formulát javasolta:

$$
D_{i}=\frac{X_{i, t-1}-X_{i, \min _{[t-2, t-n]}}}{X_{i, \max _{[t-2, t-n]}}-X_{i, \min _{[t-2, t-n]}}},
$$

ahol az $X_{i}$ egy vállalat egy adott mutatóját jelöli. A $t$ jelöli azt az évet, amelyre vonatkozóan elörejelzést kívánunk adni. Az $n$ a rendelkezésre álló idősor hossza.

A kapott eredmény azt mutatja, hogy a vállalat vizsgált pénzügyi mutatójának aktuális értéke mennyivel tér el az azt megelőző időszak minimális értékétől a legutoljára megfigyelt évet megelőző időszak szóródási terjedelmének tükrében. A számítás menetét egy 2012-ben csődbe ment magyar vállalkozás eszközarányos jövedelmezősége (ROA) mutatójának példáján szemléltetjük (1. táblázat).

Amint a táblázatból látható, a vizsgált vállalkozás mutatója jelentős időbeli szóródást mutat. 2008-tól viszont egyértelmüen romló tendencia figyelhető meg. Amennyiben az 1. táblázat adataira alkalmazzuk az (1) formulát, akkor az alábbi számítást kell elvégeznünk:

\section{1. táblázat}

Egy csődbe ment vállalkozás ROA-mutatójának idősora

\begin{tabular}{lr}
\hline Üzleti év & \multicolumn{1}{c}{ ROA } \\
\hline 2011 & $-4,9112$ \\
2010 & $-1,8360$ \\
2009 & 0,1153 \\
2008 & 0,1671 \\
2007 & 0,0403 \\
2006 & $-0,0924$ \\
2005 & $-0,1939$ \\
2004 & 0,0284 \\
2003 & $-0,4214$ \\
2002 & $-5,5220$ \\
2001 & $-1,7470$ \\
\hline
\end{tabular}
$D_{i}=\frac{X_{i, t-1}-X_{i, \min _{[t-2, t-n]}}}{X_{i, \max _{[t-2, t-n]}}-X_{i, \min _{[t-2, t-n]}}}=\frac{-4,9112-(-5,522)}{0,1671-(-5,522)}=0,107$.

Az eredmény úgy értelmezhető, hogy a vizsgált vállalkozás ROA-mutatója 2011-ben - a megelőző időszak szóródási terjedelmét 100 százaléknak tekintve - 10,7 százalékkal magasabb, mint a megelőző időszak minimuma. A mutató előrejelző képességét rontja, 
hogy a vállalatnak 2002-ben rosszabb volt a ROA-mutatója, mint a felszámolási eljárás megkezdését közvetlenül megelőző évben. A gyenge jövedelmezőség ugyan tükröződik a felszámolást megelőző évre számított dinamikus mutató értékéböl (mivel 0 közeli), figyelembe kell venni azt is, hogy a 2002-es év az idősor egy kiugró (outlier) értékének tekinthetö, ami betudható akár a vállalat kezdeti nehézségeinek is. Gyakori eset, hogy a kezdeti nehézségek miatt az induló vállalkozások pénzügyi mutatói az első években hasonlítanak a csődközeli vállalkozásokéra (Du Jardin [2010]). Ebben a példában azonban a vállalkozás tovább müködött, ezért a 2002-ben tapasztalt kiugró érték figyelembevétele torzítja az idősor alapján számítható dinamikus mutató információtartalmát.

E torzító hatás elkerülése érdekében az idősorok extrém értékeit célszerünek tünik korrigálni. Ehhez azonban elöször definiálni kell, hogy mit tekintünk kiugró értéknek. Mivel a szakirodalomban nem áll rendelkezésre objektív definíció, illetve módszer (Tsai-Cheng [2012]), így erre a célra statisztikai hüvelykujjszabályok használatosak. Nyitrai [2014a] a pénzügyi mutatószámok idősorának standardizálását javasolta a $[t-2, t-n]$ időintervallum átlagával és szórásával, azaz a legutoljára megfigyelt, $(t-1)$-edik év adatát nem használjuk fel az idősor átlagának és szórásának számításánál. A példában szereplő idősor standardizált értékeit mutatja a 2. táblázat.

Az imént idézett szerző az idősor standardizált értékei esetén azt tekintette kiugró értéknek, amely a $[-2,2]$ intervallumon kívülre esik. A szabály alkalmazására a nemzetközi szakirodalomból példaként Emel és szerzőtársai [2003] munkája említhető, ahol a szerzők szintén ezzel a módszerrel azonosították a kiugró értékeket. Elterjedt még a statisztikai elemzésekben a 3 szórásterjedelem alkalmazása is (lásd például Li-Sun [2011]). Nyitrai [2014a] megvizsgálta a dinamikus mutatók előrejelző teljesítményét a 3 és a 2 szórásterjedelem alkalmazása mellett, illetve a kiugró értékek kezelése nélkül is. Az eredmények azt mutatták, hogy a legjobb előrejelző teljesítmény a 2 szórásterjedelem alkalmazásával adódik, ezért itt ezt az eljárást követtük.

Amint a 2. táblázatból látható, a 2002-es év kiugró értéknek tekinthető az idősorban, hasonlóan a felszámolási eljárást közvetlenül megelőző 2011-es évhez. Ez a való életből vett eset szemléletes példát szolgáltat Lee és szerzőtársai [2005] azon megállapítására, miszerint a csődbe jutott vállalatok a jól működő cégekhez képest kilógnak a sorból. Amennyiben elfogadjuk a szerzők álláspontját, akkor szükségesnek tűnhet az idősorban található kiugró értékek valamilyen korrekciója a dinamikus mutatók elörejelző képességének fokozása érdekében. A kiugró értékek kezelése a gyakorlatban rendszerint helyettesítést jelent. Tekintettel arra, hogy ebben az esetben a helyettesítés egy pénzügyi mutatószám idősorának egyik szélső értékét érinti, így célszerű választásnak tűnik Nyitrai [2014a] azon megoldása, amely a kiugró értéket az idősor

\section{2. táblázat}

Egy hazai vállalkozás ROAmutatójának standardizált idősora

\begin{tabular}{lrc}
\hline Üzleti év & ROA & $\begin{array}{c}\text { Standardizált } \\
\text { ROA }\end{array}$ \\
\hline 2011 & $-4,9112$ & $-2,3599$ \\
2010 & $-1,8360$ & $-0,5296$ \\
2009 & 0,1153 & 0,6317 \\
2008 & 0,1671 & 0,6626 \\
2007 & 0,0403 & 0,5871 \\
2006 & $-0,0924$ & 0,5081 \\
2005 & $-0,1939$ & 0,4477 \\
2004 & 0,0284 & 0,5800 \\
2003 & $-0,4214$ & 0,3123 \\
2002 & $-5,5220$ & $-2,7234$ \\
2001 & $-1,7470$ & $-0,4766$ \\
\hline
\end{tabular}


hozzá legközelebbi, de már nem kiugró értékével helyettesíti. ${ }^{2}$

Hangsúlyoznunk kell, hogy a standardizáláshoz hasonlóan az idősor legelső elemét (a legújabb adatot) nem használjuk fel a helyettesítés során sem, mivel a fizetésképtelenség kialakulása feltehetően egy hosszabb folyamat következménye, amelynek jelei az előre jelezni kívánt esemény bekövetkezését közvetlenül megelőző évben mutatkoznak leginkább. Vélhetően ez az oka annak, hogy ezek az adatok játsszák a fö szerepet a csődelörejelzésben (Lin és szerzőtársai [2011]). Így a legutóbb megfigyelt év adatait nem indokolt szerepeltetni sem a standardizálás, sem pedig a helyettesítés során. Ennek megfelelően az előbbi példában az idősor 2002-es kiugró értékét a hozzá legközelebbi, de már nem kiugró 2010 -es értékkel helyettesítjük, mert figyelmen kívül hagyjuk az idősor legújabb elemét. A korrekciót követően az idősort ismételten standardizáljuk a $[t-2$, $t-n]$ időintervallum átlagával és szórásával. Az eredményeket a 3. táblázat mutatja.

A 3. táblázat első sorának adatai szerint az idősorban már csak egyetlen kiugró ${ }^{3}$ érték szerepel: a felszámolási eljárást közvetlenül megelőző év adata. Alkalmazzuk az így kapott idősorra a dinamikus mutatók (1) formuláját!

$D_{i}=\frac{X_{i, t-1}-X_{i, \min _{[t-2, t-n]}}}{X_{\left.i, \max _{[t-2, t-n]}\right]}-X_{i, \min _{[t-2, t-n]}}}=\frac{-4,9112-(-1,836)}{0,1671-(1,836)}=-1,535$.

A most kapott eredmény úgy értelmezhető, hogy a vizsgált vállalkozás ROA-mutatója a felszámolási eljárást megelőző évben 153,5 százalékkal gyengébb, mint az azt megelőző időszak minimuma, ha az azt megelőző időszak szóródásának terjedelmét 100 százaléknak tekintjük. Ez a mutató sokkal inkább tükrözi a közelgő fizetésképtelenséget, mint az, a mely a kiugró érték korrekciója nélkül adódott, így feltehetően nagyobb segítséget nyújt a modellekben a csődbe jutott vállalatok azonosításához.

Nyitrai [2014a] szerint a most bemutatott dinamikus mutatók segítségével növelhető a csődmodellek elörejelző képessége. Az idézett tanulmány következtetései csak olyan modellek eredményei alapján születtek meg, amelyek döntési fák segítségével készültek. Mivel a dinamikus mutatók gyakran vesznek fel kiugró értékeket, érdemes a döntési fák módszerét választani, mert eredményei invariánsak a kiugró értékekre (Twala [2010]).

\footnotetext{
${ }^{2}$ Hasonló megközelítést alkalmazott Zhou és szerzőtársai [2012] a hiányzó értékek pótlására.

${ }^{3} \mathrm{Az}$ alkalmazás során célszerű figyelmet fordítani arra, hogy ha az idősor a kiugró érték helyettesítését követően az új átlag és szórás alapján újra standardizálva továbbra is tartalmaz kiugró értéket, akkor a bemutatott helyettesítési eljárást mindaddig ismételni kell, amíg az új átlaggal és szórással ismételten standardizált idősor már nem tartalmaz kiugró értéket (lásd Nyitrai [2014a]).
} 
A csődelörejelzés szakirodalmában és gyakorlati alkalmazásában azonban sokkal gyakoribbnak tekinthető a logisztikus regresszió alkalmazása. Például Zhang-Thomas [2015] szerint a banki hitelpontozó rendszerek 95 százaléka is erre a módszerre épül. Ez a módszertan azonban érzékeny a kiugró értékek jelenlétére, amelyek az (1) formula által generált változóknál gyakran előfordulnak. Tanulmányunk a kiugró értékek torzító hatását a statisztikai modellezésben elterjedt helyettesítéssel kezelve vizsgálja a dinamikus mutatók alkalmazhatóságát a logisztikus regresszió keretei közt.

Az (1) képlet számításához mindenképp szükséges a vállalkozások pénzügyi mutatóinak idősora. Nyitrai [2014a] az idősorokat teljes hosszukban figyelembe vette, de ez korlátozhatja az alkalmazást a gyakorlatban. Ennek oka, hogy jelentős adatmennyiséget és számítási kapacitást igényel a teljes idősor figyelembevétele az (1) formula kiszámításakor. Továbbá ha időben túlságosan távoli időpontokat is figyelembe veszünk, akkor a dinamikus mutatók információtartalma torzulhat: egy hosszabb periódus esetében reális feltételezés lehet, hogy egy sok évvel korábbi kiugró értéknek már nincs jelentősége a jelenbeli helyzet megítélése szempontjából. Ebből adódóan kutatásunkban megvizsgáljuk a modellek teljesítményét annak függvényében, hogy az (1) formula számítása során a pénzügyi mutatók idősorait hány évre visszamenőleg vesszük figyelembe.

\section{Empirikus vizsgálat}

\section{A vizsgált adatok}

Az empirikus vizsgálathoz felhasznált adatbázis saját adatgyüjtésen alapul. A fizetésképtelenség előrejelzéseit azon hazai vállalkozások esetében vizsgáljuk, amelyekkel szemben felszámolási eljárást vagy csődeljárást indítottak. Ennek tényét a Cégjegyzék hatályos adatai alapján ellenőriztük. Működő vállalatnak azokat tekintettük, amelyekkel szemben a mintavétel időpontjáig nem került sor csőd- vagy felszámolási eljárás megindítására. A mintába került vállalkozásokat azok köréből válogattuk ki, amelyek a Cégközlöny véletlenszerüen kiválasztott számaiban hirdetményt tettek közzé. A vállalatok pénzügyi beszámolóit a 2001-2014 közötti időszakra gyüjtöttük össze (amennyiben ilyen hosszú időszakra vonatkozóan rendelkezésre álltak az adatok) a hivatalos elektronikus beszámoló portálról. ${ }^{4}$

A nyilvános adatbázisokban csak a vállalatok neve és cégjegyzékszáma alapján van lehetőség keresésre, ezért az adatgyüjtés során más szempontokat nem tudtunk figyelembe venni az alábbiak kivételével:

- csak azon vállalkozások kerülhettek a mintába, amelyeknek legalább öt egymást követő évre vonatkozóan hozzáférhetőek voltak a pénzügyi beszámolói a korábban említett elektronikus beszámoló portálon;

- nem kerülhettek a mintába azok a megfigyelések, amelyek nem realizáltak árbevételt, mivel vélhetően nem folytatnak érdemi gazdálkodási tevékenységet, így torzítanák

\footnotetext{
${ }^{4}$ Igazságügyi Minisztérium Céginformációs és az Elektronikus Cégeljárásban Közreműködő Szolgálata/Elektronikus beszámoló: http://e-beszamolo.im.gov.hu/oldal/beszamolo_kereses.
} 
az eredményeket. Ez alól kivételt jelentenek a fizetésképtelen vállalkozások abban az esetben, ha a felszámolási eljárást közvetlenül megelöző évben már nem realizáltak árbevételt.

A magyarázó változóink a Nyitrai [2014a] által felhasznált változók - ezek nevét és számításmódját a 4. táblázat mutatja.

4. táblázat

Az empirikus vizsgálathoz felhasznált pénzügyi mutatók neve és számításmódja*

\begin{tabular}{|c|c|}
\hline Mutatószám & Számítási mód \\
\hline Likviditási ráta & forgóeszközök/rövid lejáratú kötelezettségek \\
\hline Likviditási gyorsráta & (forgóeszközök - készletek)/rövid lejáratú kötelezettségek \\
\hline Pénzeszközök aránya & pénzeszközök/forgóeszközök \\
\hline Cash flow/kötelezettségek & (adózás utáni eredmény + értékcsökkenési leírás)/kötelezettségek \\
\hline $\begin{array}{l}\text { Cash flow/rövid lejáratú } \\
\text { kötelezettségek }\end{array}$ & $\begin{array}{l}\text { (adózás utáni eredmény + értékcsökkenési leírás)/rövid lejáratú } \\
\text { kötelezettségek }\end{array}$ \\
\hline Tőkeellátottság & (befektetett eszközök + készletek)/saját tőke \\
\hline Eszközök forgási sebessége & értékesítés nettó árbevétele/mérlegföösszeg \\
\hline Készletek forgási sebessége & értékesítés nettó árbevétele/készletek \\
\hline Követelések forgási ideje & követelések/értékesítés nettó árbevétele \\
\hline Eladósodottság & kötelezettségek/mérlegföösszeg \\
\hline Saját tőke aránya & saját tőke/mérlegföösszeg \\
\hline Bonitás & kötelezettségek/saját tőke \\
\hline Árbevétel-arányos nyereség & adózás utáni eredmény/értékesítés nettó árbevétele \\
\hline Eszközarányos nyereség & adózás utáni eredmény/mérlegfőösszeg \\
\hline $\begin{array}{l}\text { Követelések/rövid lejáratú } \\
\text { kötelezettségek }\end{array}$ & követelések/rövid lejáratú kötelezettségek \\
\hline Nettó forgótőke aránya & (forgóeszközök - rövid lejáratú kötelezettségek)/mérlegföösszeg \\
\hline Vállalat mérete & az eszközállomány természetes alapú logaritmusa \\
\hline Évek & a megfigyelt évek száma \\
\hline
\end{tabular}

* A mérlegadatok esetén a tárgyévi mérlegben szereplő fordulónapi záróértékeket vettük figyelembe.

Forrás: Nyitrai [2014a] 571. o.

A mutatószámok kiszámítása során azokban az esetekben, ahol a hányados nevezője nulla értéket vett volna fel, a nulla értéket eggyel helyettesítettük. A 4. táblázatban szereplő valamennyi változóra az (1) formula alapján kiszámítottuk a dinamikus pénzügyi mutatókat.

Az adatgyüjtés során 1542 hazai vállalkozás pénzügyi adatait gyüjtöttük össze a 2001-2014-es időszak vonatkozásában összesen 14657 üzleti évre. A csődbe jutott ${ }^{5}$

\footnotetext{
${ }^{5}$ A továbbiakban a csődbe jutott, illetve a fizetésképtelen kifejezésekkel utalunk azokra a vállalkozásokra, amelyekkel szemben felszámolási vagy csődeljárás megindítására került sor. A müködő, illetve
} 
vállalatok aránya $44 \%$ volt. Ezek vonatkozásában a megfigyelési időszak kezdete a felszámolási, illetve csődeljárás megindulásának évét megelőző üzleti év volt. A működő vállalkozások esetén pedig a legújabb üzleti év, amelyre vonatkozóan a beszámolók hozzáférhetők voltak. A megfigyelési periódusban indított vállalkozások esetén az első (nem teljes) üzleti évet nem vettük figyelembe. A minta méret ${ }^{6}$ és iparág szerinti megoszlását a két csoportban az 5. és 6. táblázat mutatja.

\section{5. táblázat}

A vizsgált vállalkozások méret szerinti százalékos megoszlása

\begin{tabular}{lcc}
\hline & Müködő & Csődbe jutott \\
\hline Mikrovállalat & 86,1 & 92,9 \\
Kisvállalat & 10,4 & 5,2 \\
Középvállalat & 2,7 & 1,9 \\
Nagyvállalat & 0,8 & 0,0 \\
Összesen & 100,0 & 100,0 \\
\hline
\end{tabular}

\section{6. táblázat}

A mintában szereplő vállalkozások megoszlása iparági bontásban

\begin{tabular}{lccc}
\hline Nemzetgazdasági ág & Müködő & Csődbe jutott & Összesen \\
\hline Építöipar & 6,1 & 14,2 & 9,7 \\
Feldolgozóipar & 9,1 & 15,5 & 11,9 \\
Információ és kommunikáció & 7,9 & 3,7 & 6,0 \\
Ingatlan & 10,6 & 6,5 & 8,8 \\
Kereskedelem & 25,4 & 28,8 & 26,9 \\
Szakmai, müszaki szolgáltatás, tudományos & 22,0 & 8,7 & 16,1 \\
tevékenység & 18,9 & 22,6 & 20,5 \\
Egyéb* & 100,0 & 100,0 & 100,0 \\
Összesen & & &
\end{tabular}

* A túl részletes tagolás elkerülése érdekében azon további tíz nemzetgazdasági ágba sorolható vállalkozások kerültek ide, amelyek aránya nem érte el a teljes minta 5 százalékát. A legnagyobb részarányt a csődbe jutott vállalkozások vonatkozásában a szállítmányozási szektor tette ki (7,5 százalék), a működő cégek esetén pedig a szálláshel-szolgáltatás és vendéglátás ( 3,8 százalék).

fizetőképes kifejezésekkel pedig azokra a vállalatokra utalunk, amelyekkel szemben egyik előbb említett eljárásra sem került sor a mintavétel időpontjáig.

${ }^{6}$ A 2004. évi XXXIV., a kis- és középvállalkozásokról, fejlődésük támogatásáról szóló törvény alapján meghatározott mérlegföösszeg szerinti kategóriák. Hasonló tendencia mutatkozott az árbevételre vonatkozó értékhatárok szerinti csoportosítás esetén is, ezért azt nem közöltük. Létszámra vonatkozó információk sajnos nem álltak rendelkezésre az adatgyűjtés során, így a létszámot nem tudtuk figyelembe venni a kategorizálás során, annak ellenére, hogy a törvény azt is figyelembe veszi a mikro-, kis- és középvállalkozások meghatározásakor. 
Látható, hogy a vizsgált vállalkozások túlnyomó többsége mikro-, illetve kisvállalat. A közepes, illetve nagyvállalatok aránya alacsony elemszámok, így az adatbázis méret szerinti particionálását nem tartottuk célszerünek, ugyanis alacsony elemszámok nem tették volna lehetővé statisztikai modellek felállítását, illetve tesztelését. Mindebből természetesen következik az is, hogy a tanulmányban levont következtetések is elsősorban a hazai mikro-, illetve kisvállalatokra érvényesek.

$\mathrm{Az}$ adatok modellezésre történő előkészítése során minden statikus és dinamikus mutatót standardizáltunk, és a 3 szórás terjedelmen kívüli értékeket hozzáigazítottuk az adatbázis hozzájuk legközelebb lévő, 3 terjedelmen belüli értékéhez. Tekintettel arra, hogy a helyettesítést követően megváltozik a változó átlaga és szórása, gyakran előfordult, hogy ezen új átlaggal és szórással ismét standardizálva a változók értékkészletét, néhány érték továbbra is a 3 szórás terjedelmen kívül maradt. ${ }^{7}$ Ilyenkor a helyettesítést és a standardizálást mindaddig folytattuk, amíg az új átlaggal és szórással standardizált értékek nem kerültek a fenti terjedelmen belülre.

\section{Módszertan}

Az empirikus vizsgálatok során a csődelőrejelzés szakirodalmában általánosan elterjedt logisztikus regresszió módszerét alkalmaztuk. Az eljárás matematikai-statisztikai hátterét nem fejtjük ki bővebben, azt például Virág és szerzőtársai [2013] részletesen tartalmazza.

Kutatásunk célja a modellek elörejelző képességének összevetése volt, s ehhez a nemzetközi szakirodalomban általánosan elterjedt keresztvalidáció módszerét alkalmaztuk. Ennek lényege, hogy a rendelkezésre álló adathalmazt tíz egyenlő részre osztottuk oly módon, hogy minden tized azonos arányban tartalmazzon működő és csődbe jutott megfigyeléseket. A modelleket a rendelkezésre álló adatbázis 90 százalékának felhasználásával állítottuk fel, előrejelző teljesítményüket pedig a maradék 10 százalék segítségével teszteltük. A tíz modellt oly módon alkottuk meg, hogy az adatbázis minden tizede szerepeljen egyszer tesztmintaként is. Az eljárás célja annak kiküszöbölése, hogy következtetéseinket egyetlen véletlenszerüen kiválasztott tanuló-tesztelő mintafelosztásra alapozzuk. Ez a gyakorlat ugyanis könnyen vezethet téves következtetésekhez. A keresztvalidációval lényegesen robusztusabb megállapításokat tehetünk. A modellek elörejelző teljesítményét a ROC- (receiver operating characteristic) görbe alatti terület segítségével ítéltük meg. ${ }^{8}$

\footnotetext{
${ }^{7}$ Ilyen esetek általában olyankor fordultak elö, amikor a hányados típusú pénzügyi mutató nevezője nulla volt, s ezért az adatvesztés elkerülése érdekében 1-gyel helyettesítettük a 0 -t. A bemutatott többszörös standardizálás az 1-gyel történő osztás miatt megjelent kiugró értékek torzító hatását teljes mértékben kiküszöbölte az adatbázisból.

${ }^{8}$ A számításokat az SPSS Statistics 22 logisztikus regresszió és ROC-görbe funkcióival végeztük az alapértelmezett beállítások megtartása mellett. A szignifikáns változók szelekciójára a szoftver által felkínált lehetőségek közül a lépésenkénti forward eljárást (stepwise forward conditional) alkalmaztuk.
} 


\section{Az empirikus vizsgálatok eredményei}

Elsőként tekintsük azon logisztikus regresszióval felállított modellek átlagos teljesítményét, amelyek esetében a pénzügyi mutatószámok idősorait teljes egészükben figyelembe vettük az (1) formula kalkulációja során.

Mivel a tanulmány a modellek elörejelző képességét kívánja vizsgálni, ezért a könynyebb áttekinthetőség érdekében csak a tesztelőmintákra vonatkozóan kapott eredményeket közöljük. A ROC-görbe alatti terület a klasszifikációs modellek diszkrimináló erejének elterjedt mutatója. Chi-Hsu [2012] meghatározása szerint a ROC-görbe alatti terület azt mutatja meg, hogy egy modell milyen eséllyel rendel nagyobb csődkockázatot egy valóban csődbe jutott céghez, mint egy működő vállalathoz. Valószínűségről lévén szó, a ROC-görbe alatti terület legfeljebb 100 százalék lehet, így a 90 százalék körüli eredmények meglehetősen magas diszkrimináló erőt jeleznek. Kiváltképp igaz ez akkor, ha ezek a számok a tesztelömintákon kapott eredményekre vonatkoznak. A 7. táblázat eredményei azt mutatják, hogy a kiugró értékek kezelését követően a Nyitrai [2014a] által javasolt mutatószámok a logisztikus regresszió keretei közt is növelik a modellek előrejelző képességét. Ezekkel az indikátorokkal a pusztán statikus mutatók melletti 89,2 százalékos átlagos ROC-görbe alatti terület 91,2 százalékra növekedett.

\section{7. táblázat}

A modellek átlagos teljesítménye a tesztelőmintákra vonatkozóan (százalék)

\begin{tabular}{lcc}
\hline Változócsoport & Minta & ROC-görbe alatti terület \\
\hline \multirow{2}{*}{ Statikus } & tanuló & 89,8 \\
& tesztelő & 89,2 \\
Statikus és dinamikus & tanuló & 92,0 \\
& tesztelő & 91,2 \\
\hline
\end{tabular}

Tanulmányunk másik célja annak vizsgálata volt, hogy miként befolyásolja a modellek elörejelző képességét, ha az (1) képlet számítása során nem vesszük figyelembe a pénzügyi mutatók teljes idősorát. Mivel ehhez minimum három üzleti év adatára van szükség, így az idősorok lehetséges hossza 3 és 14 év között mozog. Ebben a tartományban a 3-11 év közti intervallumot volt lehetöségünk vizsgálni, ugyanis a mintában szereplö 12-14 éves cégek közül olyan kevesen jutottak csődbe, hogy ott nem volt lehetőség modellépítésre, illetve keresztvalidációs tesztelésre.

Az idősorok hosszának vizsgálatához az (1) formulát azzal a változtatással számoltuk újra, hogy a teljes idősor helyett csak az utolsó 3-11 évre vonatkozó adatokat használtuk fel. Az 1. ábra a figyelembe vett idősor hossza és a modellek tesztelömintákon tapasztalt átlagos ROC-görbe alatti területe közti kapcsolatot mutatja. A hat évnél ábrázolt eredmény például azon modellek átlagos előrejelző képességét szemlélteti, amelyeknek legalább hat évre rendelkezésre álltak a pénzügyi adatai, és azok alapján az (1) formula kalkulálható oly módon, hogy csak hat évre visszamenőleg vesszük figyelembe az idősor értékeit. 
1. ábra

A figyelembe vett idősor hossza és a ROC-görbe alatti terület kapcsolata (százalék)

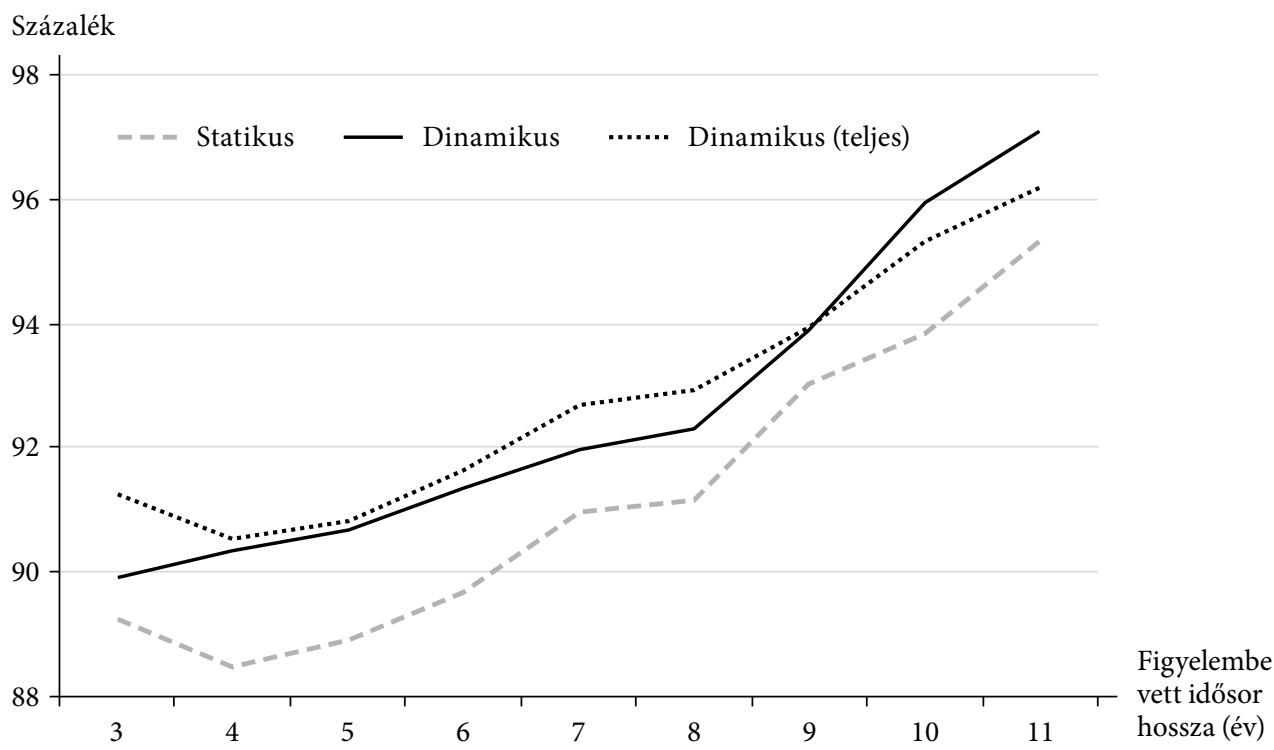

Az 1. ábra alapján arra következtethetünk, hogy minél hosszabb idősor áll a vállalkozások pénzügyi mutatóiról rendelkezésre, annál magasabb elörejelző képességü csődmodell állítható fel - függetlenül a vizsgált magyarázó tényezők körétől. Tehát a számviteli adatok alapján kalkulált pénzügyi mutatók előrejelző képessége párhuzamosan növekszik a rendelkezésre álló adatsor hosszával. Azt is megállapíthatjuk, hogy minden esetben pozitív volt az (1) formula alkalmazásának hozzáadott értéke a modellek átlagos ROC-görbe alatti területéhez, ami megerösíti Nyitrai [2014a] döntési fákkal kapott eredményeit. Az ábrán azt is láthatjuk, hogy a dinamizálási megközelítés közepes méretű idősorok (körülbelül kilenc év) esetében valamelyest kisebb mértékben javítja az eredményeket, mint a közepesnél rövidebb, illetve hoszszabb idősorok esetében.

$\mathrm{Az}$ 1. ábrán látható átlagos ROC-görbe alatti terület relatíve magasnak mondható, ha összevetjük például a Bauer-Endrész [2016] tanulmánnyal. Fontos azonban hangsúlyoznunk, hogy közvetlen összevetésre sajnos nincs mód sem az imént idézett, sem más tanulmánnyal, ugyanis a modellek függő változója (a csőd definíciója) eltérő. Bauer-Endrész [2016] például a $t$-edik időpontban csődbe jutottnak tekintette azokat a megfigyeléseket, amelyekkel szemben a $(t+1)$-edik vagy a $(t+2)$-edik időpontban csőd- vagy felszámolási eljárásra került sor. Mi csak azokat a vállalatokat tekintettük csődbe jutottnak, amelyekkel szemben a $(t+1)$-edik évben indultak ilyen eljárások. Intuitív módon is belátható, hogy a csődesemény bekövetkezéséhez közeledve a csőd jelei is egyre jobban megmutatkoznak a pénzügyi adatokon. Feltehetően ez az elsődleges magyarázata a Bauer-Endrész [2016] modellteljesítményéhez képesti magasabb értékeknek, de különbség van - egyebek mellett - az alkalmazott módszertan és a kiugró értékek kezelésének módja tekintetében is. 
Kutatásunk arra a kérdésre is választ keresett, hogy érdemes-e a rendelkezésre álló idősorokat teljes hosszukban figyelembe venni, vagy elegendő egységesen csak az utolsó 3-11 évet megfigyelni. Az 1. ábra Teljes elnevezésü görbéje mutatja azon modellek átlagos eredményeit, amelyek esetén a dinamikus mutatók számításához a teljes rendelkezésre álló idősorokat felhasználtuk. Ebből azt láthatjuk, hogy ha a vállalatokra vonatkozóan legalább kilencéves idősor áll rendelkezésre, akkor a dinamikus mutatók a teljes idősort figyelembe véve nagyobb mértékben növelik a modellek előrejelző teljesítményét, mint ha csak az idősorok utolsó 3-9 évét vennénk figyelembe. Kilenc évnél hosszabb idősorok esetén azonban már azok a modellek növelték jobban a ROC-görbe alatti területet, amelyek csak az utolsó 10-11 év szélső értékeit használták fel viszonyítási alapként.

Az eredmények azt mutatják, hogy körülbelül egy évtized múltán a mintában szereplő vállalkozások pénzügyi mutatói mint viszonyítási alapok „elavulnak”, az ennél frissebb adatokat azonban célszerü figyelembe venni referenciaként, mivel azok tükrében a legutoljára megfigyelt év adataira nagyobb előrejelző képességgel jellemezhető modellek építhetők a hagyományos módszerek körébe tartozó logisztikus regresszió kereteinek használata esetén is.

\section{Robusztusságvizsgálatok}

Az imént levont következtetések megalapozottságának vizsgálata céljából a fent bemutatott elemzést elvégeztük az adatbázis homogénebb részhalmazain is. Ezek meghatározásakor figyelni kellett arra, hogy a modellezéshez és a teszteléshez is elegendő számú megfigyelés álljon rendelkezésre, ezért az empirikus vizsgálatot megismételtük a mérlegföösszegük alapján mikrovállalkozásokra és a rendelkezésre álló adatbázisban legnagyobb arányt képviselő, kereskedelmi ágazatban tevékenykedő cégekre is. A végrehajtott elemzések minden tekintetben megegyeztek a korábbiakkal, viszont a megfigyelések alacsonyabb száma már nem tette lehetővé a tízszeres keresztvalidáció alkalmazását a legalább 8-11 elemü adatsorok esetén, ugyanis a tesztelési adatbázis elemszáma nem érte volna el a százat, ezért ezekben az esetekben a keresztvalidáció tagszámát csökkentettük ${ }^{9}$ a legalább százelemü tesztelési mintaméret biztosítása érdekében. A számítások eredményeit a 2. ábra mutatja.

A 2. ábrán teljesen azonos tendenciák tapasztalhatók, mint amit a teljes adatbázis esetében korábban az 1. ábrán láthattunk:

- A rendelkezésre álló idősor hosszának növekedésével jellemzően növekszik a modellek előrejelző képessége.

- A tíz évnél rövidebb idősorok esetében az elörejelző képességet jobban növeli, ha viszonyítási alapként a teljes idősort vesszük figyelembe, mint ha csak az idősor utolsó 3-9 évét; a tíz évnél hosszabb idősorok esetében azonban az előrejelző

\footnotetext{
${ }^{9}$ Legalább nyolcelemű idősorok esetén kilencszeres, legalább kilencelemủ idősorok esetén hétszeres, legalább tízelemű idősorok esetén hatszoros, legalább tizenegy elemü idősorok esetén pedig ötszörös keresztvalidációt alkalmaztunk.
} 


\section{2. ábra}

A mérlegföösszegük alapján mikrovállalkozások figyelembe vett idősorai hosszának és a ROC-görbe alatti területnek a kapcsolata (százalék)

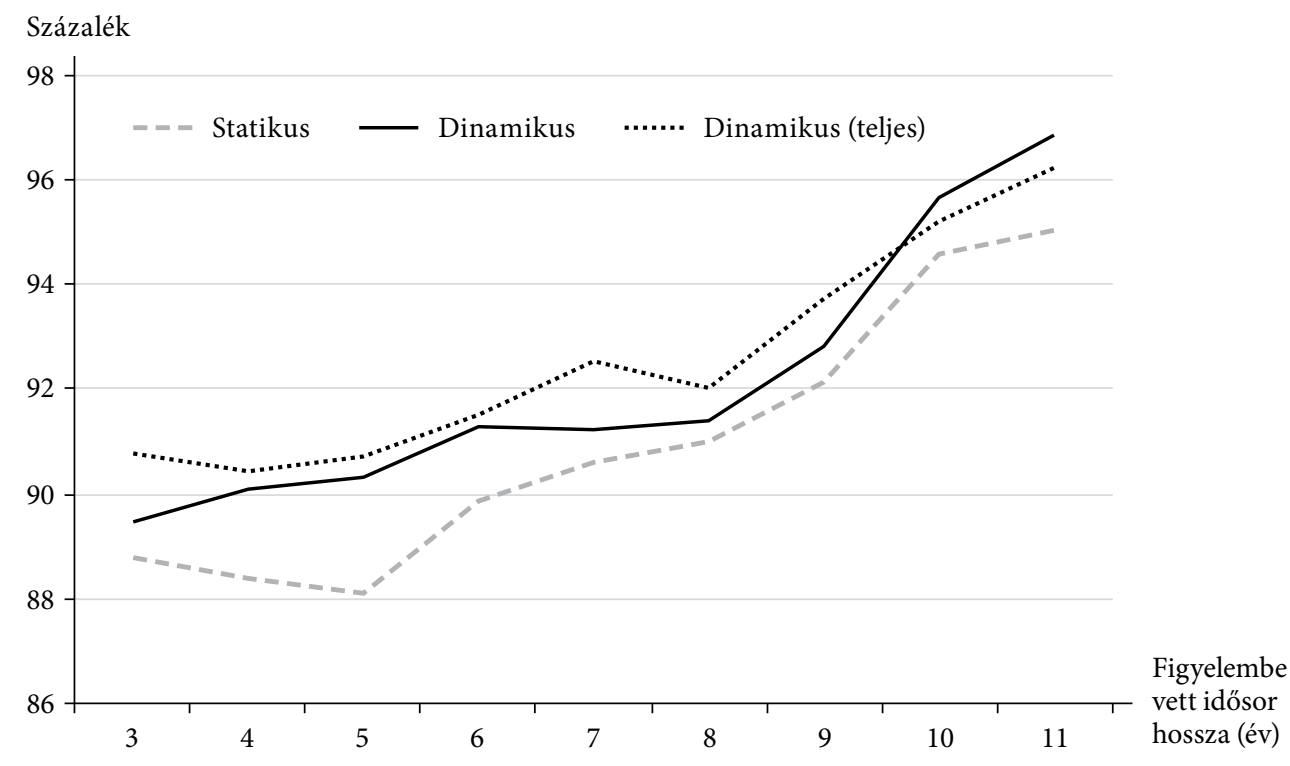

képességet az növeli jobban, ha az (1) formula számításakor csak az utolsó tíz év szélső értékeit vesszük figyelembe.

- Az idősor hosszától függetlenül érvényes, hogy az (1) formula alkalmazása a statikus mutatók önálló alkalmazásához képest növeli a modellek előrejelző képességét.

A modellezést külön elvégeztük azokra a vállalatokra is, amelyek valamely kereskedelmi tevékenységet jelölték meg fö tevékenységükként. Mivel ez a korlátozás a felénél is kevesebbre csökkentette a rendelkezésre álló megfigyelések számát, ezért a korábban alkalmazott keresztvalidációtól eltérő validációs módszert kellett választanunk a tesztelőminta megfelelő számossága érdekében: a rendelkezésre álló adathalmazt ötször osztottuk fel véletlenszerüen $2 / 3: 1 / 3$ arányban tanuló-, illetve tesztelőmintákra, majd a tesztelőmintákon kapott ROC-görbe alatti területeket átlagoltuk. Az eredményeket a 3. ábra mutatja.

A 3. ábrán látható eredmények szintén megerősítik a korábbi következtetéseket.

- A korábbi ábrákon is megfigyelhető volt, hogy rövidebb idősorok alkalmazása esetén a modellek elörejelző teljesítménye némileg alacsonyabb a többi esethez képest; ez a tendencia még erősebben megmutatkozott a kereskedelemmel foglalkozó vállalkozások vizsgálata esetén.

- Tíz évnél rövidebb idősorok esetén célszerübb a teljes idősort felhasználni viszonyítási alapként, mint csak az utolsó 3-9 évet, mert az utóbbi esetben az (1) formula alkalmazásával kapott dinamikus mutatók szerepeltetése kevésbé növeli (sőt néhány esetben minimálisan csökkenti) a modellek teljesítményét ahhoz képest, mint ha a teljes idősort felhasználtuk volna. Tíz évnél hosszabb idősorok esetén azonban célszerübbnek tünik csak az utolsó tíz év alkalmazása. 


\section{3. ábra}

A kereskedelmi szektorban figyelembe vett idősor hossza és a ROC-görbe alatti terület kapcsolata (százalék)

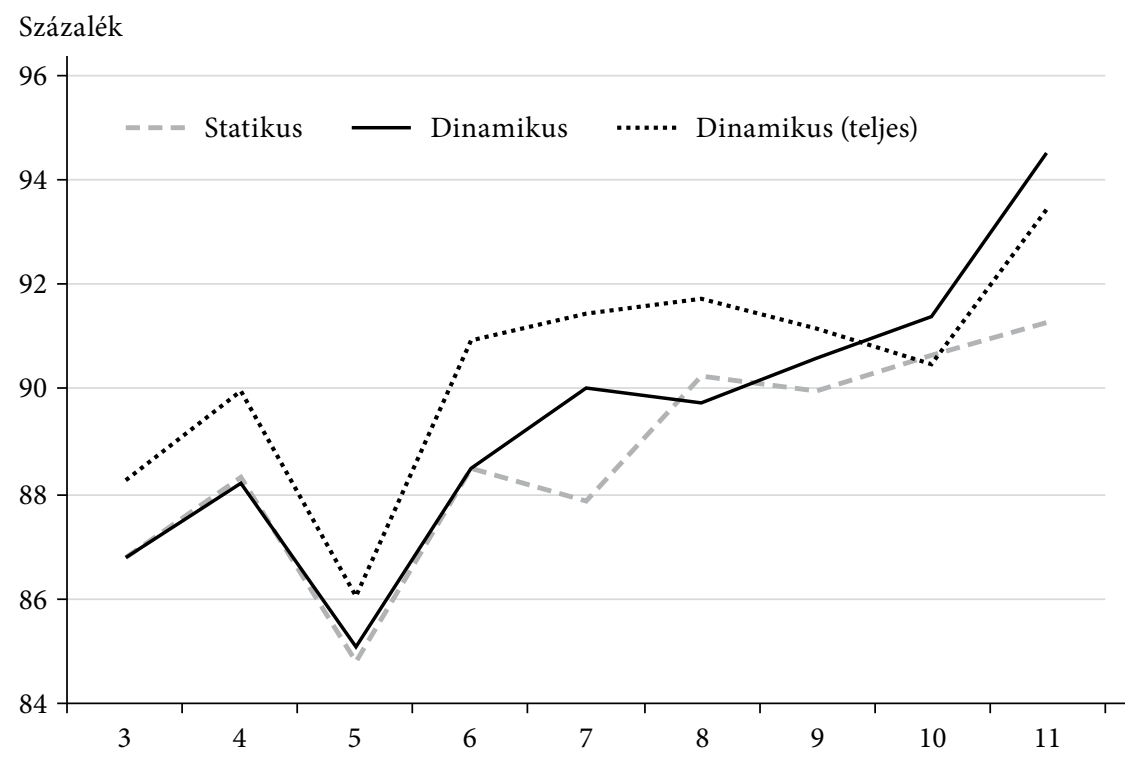

Figyelembe vett idősor hossza (év)

- Az (1) formula számításánál megfelelő idősorhosszúságot figyelembe véve minden esetben magasabb volt a dinamikus mutatókat is tartalmazó modellek átlagos ROC-görbe alatti területe, mint ha a modelleket pusztán statikus változókra építettük volna.

\section{Összegzés}

Tanulmányunk kiindulópontja az a megfigyelés volt, hogy a csődelőrejelző modellek alapvetően statikus jellegüek, ami azt jelenti, hogy a modellek magyarázó változói közt csak a legutoljára megfigyelt üzleti év pénzügyi mutatóit használják fel, figyelmen kívül hagyva időbeli tendenciájukat. A probléma kiküszöbölése érdekében Nyitrai [2014a] javasolt egy lehetséges formulát, amelynek hatékonyságát döntési fákat használó empirikus vizsgálatok alátámasztották. Az idézett tanulmány azonban számos kérdést nyitva hagyott, melyek közül a következökre kerestünk választ:

- A logisztikus regresszió módszerével felállított modellek esetében is növeli-e a modellek elörejelző képességét az (1) formulával kalkulálható változók használata?

- Hogyan befolyásolja a pénzügyi mutatók megfigyelt idősorainak hossza az (1) képlettel kiszámított dinamikus változókat is tartalmazó modellek elörejelző képességét?

Empirikus vizsgálatainkhoz hazai vállalkozásokra gyüjtöttünk adatokat a 20012014-es időszakra vonatkozó nyilvános adatforrásokból. A több mint 1500 megfigyelést tartalmazó adatbázison több száz modellt állítottunk fel a tízszeres kereszt- 
validáció részeként. A modellek elörejelző teljesítményét a ROC-görbe alatti területtel mértük, amely a klasszifikációs modellek teljesítményének általános elfogadott méröszáma. A fenti kérdésekre az alábbi válaszokat kaptuk:

- A Nyitrai [2014a] által javasolt dinamizálási eljárás a paraméteres statisztikai módszerek körébe sorolható logisztikus regresszió keretei közt is hatékonynak bizonyult a modellek előrejelző teljesítményének növelése szempontjából.

- Rövidebb idősorok (legalább 3-9 év adata) esetén célszerü a teljes adatsort felhasználni az (1) képlet számítása során, hosszabb idősoroknál (legalább tíz év) azonban már csak az utolsó tíz év adatait érdemes figyelembe venni az előrejelző képesség maximalizálása érdekében.

Következtetéseink megalapozottságát a mikrovállalkozásokra és a kereskedelmi szektorra vonatkozóan elvégzett robusztusságvizsgálatok is megerősítették. Kutatási eredményeink arra utalnak, hogy a pénzügyi mutatók statikus értékei mellett célszerü figyelmet fordítani időbeli tendenciáikra is. Tíz évnél fiatalabb vállalkozások esetében a teljes idősor tükrében, ennél idősebb cégeknél pedig az utolsó évtized tükrében érdemes megítélni a modellek előrejelző képességét.

A bemutatott elemzés közel sem tekinthető teljesnek. Az eredmények további megerősítése, illetve a módszer továbbfejlesztése számos jövőbeli kutatási lehetőséget rejt magában.

- A tanulmányban a csődöt jogi értelemben definiáltuk. Érdekes vizsgálati terület lehet a banki gyakorlatban alkalmazott bedőlési definíció alapján is vizsgálni a dinamizálás most alkalmazott metódusát.

- A pénzügyi mutatók értékeit a vállalati gazdálkodás sajátosságai mellett makrogazdasági tendenciák is befolyásolhatják (Bauer-Endrész [2016]), amelyeket célszerü lehet figyelembe venni a modellek előrejelző teljesítményének további növelése érdekében.

- Az (1) formulával definiált változók előrejelző képessége vizsgálható a legkorszerübb klasszifikációs eljárások (például neurális hálók) keretei közt is.

\section{Hivatkozások}

Altman, E. I. [1968]: Financial ratios, discriminant analysis and the prediction of corporate bankruptcy. The Journal of Finance, Vol. 23. No. 4. 589-609. o. http://dx.doi.org/0.1111/ j.1540-6261.1968.tb00843.x.

BAUer PÉTER-EndrÉsz Mariann [2016]: Modelling bankruptcy using Hungarian firm-level data. MNB Occasional Papers 122. Magyar Nemzeti Bank, Budapest. https://www.mnb. hu/letoltes/mnb-op-122-final.pdf.

Beaver, W. H. [1966]: Financial ratios as predictors of failure. Journal of Accounting Research, Vol. 4. No. 1. 71-111. o. http://dx.doi.org/10.2307/2490171.

CHEN, J. H. [2012]: Developing SFNN models to predict financial distress of construction companies. Expert Systems with Applications, Vol. 39. No. 1. 823-827. o. http://dx.doi. org/10.1016/j.eswa.2011.07.080. 
Chen, N.-Riberio, B.-Vieira, A.-Chen, A. [2013]: Clustering and visualization of bankruptcy trajectory using self-organizing map. Expert Systems with Applications, Vol. 40. No. 1. 385-393. o. http://dx.doi.org/10.1016/j.eswa.2012.07.047.

CHI, B. W.-Hsu, C. C. [2012]: A hybrid approach to integrate genetic algorithm into dual scoring model in enhancing the performance of credit scoring model. Expert Systems with Applications, Vol. 39. No. 3. 2650-2661. o. https://doi.org/10.1016/j.eswa.2011.08.120.

Du JARDIN, P. [2010]: Predicting bankruptcy using neural networks and other classification methods: The influence of variable selection techniques on model accuracy. Neurocomputing, Vol. 73. No. 10-12. 2047-2060. o. https://doi.org/10.1016/j.neucom.2009.11.034.

Emel, A. B.-Oral, M.-Reisman, A.-Yolalan, R. [2003]: A credit scoring approach for the commercial banking sector. Socio-Economic Planning Sciences, Vol. 37. No. 10. 103-123. o. http://dx.doi.org/10.1016/s0038-0121(02)00044-7.

KIM, M. J.-KANG, D. K. [2012]: Classifiers selection in ensembles using genetic algorithms for bankruptcy prediction. Expert Systems with Applications, Vol. 39. No. 10. 9308-9314. o. http://dx.doi.org/10.1016/j.eswa.2012.02.072.

Lee, K.-Boотh, D.-Alam, P. [2005]: A comparison of supervised and unsupervised neural networks in predicting bankruptcy of Korean firms. Expert Systems with Applications, Vol. 29. No. 1. 1-16. o. http://dx.doi.org/10.1016/j.eswa.2005.01.004.

LI, H.-Sun, J. [2011]: On performance of case-based reasoning in Chinese business failure prediction from sensitivity, specifity, positive and negatíve values. Applied Soft Computing, Vol. 11. No. 1. 460-467. o. http://dx.doi.org/10.1016/j.asoc.2009.12.005.

Lin, F.-Liang, D.-Chen, E. [2011]: Financial ratio selection for business crisis prediction. Expert Systems with Applications, Vol. 38. No. 12. 15094-15102. o. http://dx.doi. org/10.1016/j.eswa.2011.05.035.

Niklis, D.-Doumpos, M.-Zopounidis, C. [2014]: Combining market and accounting-based models for credit scoring using a classification scheme based on support vector machines. Applied Mathematics and Computation, Vol. 234. 69-81. o. http://dx.doi.org/10.1016/j. amc.2014.02.028.

Nwogugu, M. [2006]: Decision-making, risk and corporate governance: New dynamic models/ algorithms and optimization for bankruptcy decisions. Applied Mathematics and Computation, Vol. 169. No. 1. 386-401. o. http://dx.doi.org/10.1016/j.amc.2005.11.140.

Nwogugu, M. [2007]: Decision-making, risk and corporate governance: A critique of methodological issues in bankruptcy/recovery prediction models. Applied Mathematics and Computation, Vol. 185. No. 1. 178-196. o. http://dx.doi.org/10.1016/j.amc.2005.11.178.

Nyitrai TAMÁs [2014a]: Növelhető-e a csődelőrejelző modellek előrejelző képessége az új klaszszifikációs módszerek alkalmazása nélkül? Közgazdasági Szemle, 61. évf. 4. sz. 566-585. o.

Nyitrai TamÁs [2014b]: Validációs eljárások a csődelőrejelző modellek teljesítményének megítélésében. Statisztikai Szemle, 92. évf. 4. sz. 357-377. o.

Oreski, S.-Oreski, D.-Oreski, G. [2012]: Hybrid system with genetic algorithm and artificial neural networks and its application to retail credit risk assessment. Expert Systems with Applications, Vol. 39. No. 16. 12605-12617. o. http://dx.doi.org/10.1016/j.eswa.2012.05.023.

Platt, H. D.-Platt, M. B. [1990]: Development of a class of stable predictive variables: The case of bankruptcy prediction. Journal of Business Finance and Accounting, Vol. 17. No. 1. 31-51. o. http://dx.doi.org/10.1111/j.1468-5957.1990.tb00548.x.

Platt, H. D.-Platt, M. B. [2002]: Predicting corporate financial distress: Reflections on choice-based sample bias. Journal of Economics and Finance, Vol. 26. No. 2. 184-199. o. http://dx.doi.org/10.1007/bf02755985. 
Riberio, B.-Silva, C.-Chen, N.-Vieira, A.-Das Neves, J. C. [2012]: Enhanced default risk models with SVM+. Expert Systems with Applications, Vol. 39. No. 11. 10140-10152. o. http://dx.doi.org/10.1016/j.eswa.2012.02.142.

Sánchez-Lasheras, F.-De Andrés, J.-Lorca, P.-De Cos Juez, F. J. [2012]: A hybrid device for the solution of sampling bias problems in the forecasting of firms' bankruptcy. Expert Systems with Applications, Vol. 39. 7512-7523. o. http://dx.doi.org/10.1016/j. eswa.2012.01.135.

Sun, L. [2007]: A re-evaluation of auditors' opinions versus statistical models in bankruptcy prediction. Review of Quantitative Finance and Accounting, Vol. 28. No. 1. 55-78. o. http:// dx.doi.org/10.1007/s11156-006-0003-X.

Tsai, C. F.-Cheng, K. C. [2012]: Simple instance selection for bankruptcy prediction. Knowledge-Based Systems, Vol. 27. 333-342. o. http://dx.doi.org/10.1016/j.knosys.2011.09.017.

Twala, B. [2010]: Multiple classifier application to credit risk assessment. Expert Systems with Applications, Vol. 37. No. 4. 3326-3336. o. http://dx.doi.org/10.1016/j.eswa.2009.10.018.

Virág Miklós-Kristóf Tamás-Fiáth Attila-Varsányi Judit [2013]: Pénzügyi elemzés, csődelőrejelzés, válságkezelés. Kossuth Kiadó, Budapest.

Virág Miklós-Nyitrai Tamás [2015]: Csődelőrejelző modellek dinamizálása - a szakértői tudás megjelenítése a csődelőrejelzésben. Megjelent: Bakacsi Gyula-Balaton Károly (szerk.): Vezetés és szervezet társadalmi kontextusban. Tanulmányok Dobák Miklós 60. születésnapja tiszteletére. Akadémiai Kiadó, Budapest, 284-304. o.

Zhang, J.-Thomas, L. C. [2015]: The effect of introducing economic variables into credit scorecards: An example from invoice discounting. Journal of Risk Model Validation, Vol. 9. No. 1. 57-78. o. http://dx.doi.org/10.21314/JRMV.2015.134.

ZHou, L. [2013]: Performance of corporate bankruptcy prediction models on imbalanced dataset: The effect of sampling methods. Knowledge-Based Systems, Vol. 41. No. 8. 16-25. o. http://dx.doi.org/10.1016/j.knosys.2012.12.007.

ZHOU, L.-LAI, K. K.-YEN, J. [2012]: Empirical models based on features ranking techniques for corporate financial distress prediction. Computers and Mathematics with Applications, Vol. 64. 2484-2496. o. http://dx.doi.org/10.1016/j.camwa.2012.06.003. 